\title{
'A Barricade across the High Road': C.S. Lewis on the theology of his time
}

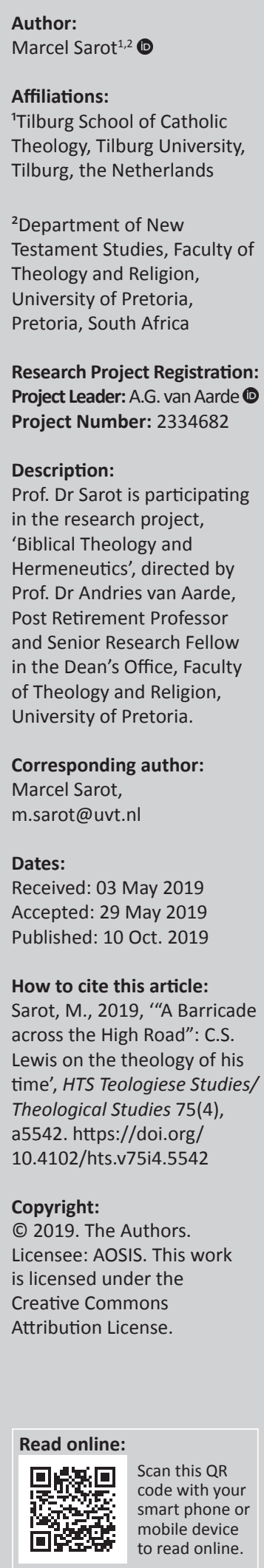

\begin{abstract}
In this article, I analyse C.S. Lewis's attitude towards the theology and the theologians of his time. Lewis often emphasised that he was not a theologian. Sometimes he does so out of modesty, to excuse minor errors that a specialist in the field would not have made. More often than not, however, something else plays a role: Lewis's dislike of the theology and the theologians of his time. Although he intended not to become a party in theological controversies, Lewis occasionally took sides. He expressed himself in extremely negative terms about the liberal ... movement, which in his experience... dominated the theology of his time. By assuming them to be in error, and showing how they had arrived there, he participates in the practice he elsewhere rejected as 'Bulverism'. Moreover, he employed pejorative, sexually tinged metaphors. Only on one occasion did Lewis provide arguments for his rejection of liberal theology, and on that occasion he limited himself to New Testament exegesis. On another occasion, Lewis states that he allows only marginal, religiously irrelevant revisions of Christian doctrine. Ironically, his own revisions sometimes went beyond this - for example, in the case of the traditional doctrine of hell. In this article I suggested that for Lewis, the practice of faith implicitly is the ultimate criterion.
\end{abstract}

Keywords: C.S. Lewis; Theology; Liberal theology; Bulverism; Hell; Doctrinal development.

\section{Introduction: Theologians on Lewis}

In a letter of 28 June 1963 to Jocelyn Gibb, Lewis explained that he saw 'recent Anglican theology ... as a barricade across the high road' hindering 'the wayfaring Christian' (Lewis 1963:371; cf. Hooper 1996:380). ${ }^{1}$ When C.S. Lewis discussed some contemporary theology in Letters to Malcolm, this was not because he thought he or his readers could learn from it, but because it was an obstacle he and they could not avoid. C.S. Lewis did not like theologians, and theologians do not like C.S. Lewis (MacSwain 2010:1-4).

This seems to me a fair summary of the relationship between C.S. Lewis and theology. Lewis himself repeated so often that he was not a theologian at all, and continued to repeat this so consistently even after having received an honorary doctorate in theology from the University of St Andrews in 1946 (Lewis 1940:viii, 1944a:60, 62, 1959:191, 193, 1964:19; cf. Travers 2007:38-40), that at a certain moment one begins to wonder: Is this mere modesty, or is it a clever way of distancing himself from professional theologians? Vice versa, in spite of that early honorary doctorate, theologians never really warmed to Lewis.

That first honorary doctorate, therefore, was to remain the only one. Theologians have called C.S. Lewis a 'glue pot theologian', a sort of theological toddler who copies and pastes passages from the work of others while hardly understanding these himself (W.J. van Asselt $\uparrow$, Utrecht University, pers. comm., 2002) or they say condescendingly that he was 'a good apologist but a poor theologian' (Gilley 2006), or they chastise him for 'his lack of theological sophistication' (Dorsett \& Hanson 2007:293) or even for being 'shockingly crude' (Pittenger 1950; cf. Lewis 1944b:177). Even those who sympathise with his work underline that Lewis never studied theology and although he has occasional strokes of brilliance - makes the most elementary mistakes. Thus, the Anglican Bishop N.T. Wright writes about Mere Christianity:

The weakest part of the book, beyond doubt, is its heart: the treatment of God, and especially of Jesus, in the second section, 'What Christians Believe'. He simply does not know that Jesus wasn't born in A.D. 1, and I have already mentioned the astonishing absence of the Resurrection. ... Why was this? ... Perhaps he simply had to give some talks and decided too quickly and unreflectively on which topics to treat. But

1.The quote became part of the blurb text of the first edition Letters to Malcolm. See Vaus (2007:2011-2012). 
of course the real problem is the argument for Jesus' divinity. And this problem actually begins further back: There is virtually no mention, and certainly no treatment, of Israel and the Old Testament, and consequently no attempt to place Jesus in his historical or theological context. (Abridged from Wright 2007)

If even a kindred spirit like Wright, who was already influenced by Lewis as a student, is so critical of Lewis, how about other theologians? It is easy to guess: just like Wright's teachers in Oxford, they look down their nose at Lewis.

\section{Lewis on theologians: Two case studies}

However, this article is not about theologians' opinions about Lewis, but about Lewis's opinions about theologians. What did Lewis think about the theologians and the theology of his time? ${ }^{2}$ Did Lewis indeed distance himself from theology, as I just suggested? Or did Lewis emphasise that he was not a theologian out of modesty or because he was aware that because of his lack of professional training in theology he was prone to make minor mistakes?

Lewis certainly was aware of his own limitations as a theological scholar (Travers 2007:38-40), but it is obvious that his dislike of the theologians of his day also played a role. Whenever Lewis mentions contemporary theologians, he does so with a certain disdain. As Kevin Vanhoozer acutely observes, Lewis 'considered the matter of Christian faith too important to be left to the clergy, and to the theologians' (Vanhoozer 2010:76).

Lewis explains his attitude at greater length in The Great Divorce, a theological novella in which a number of inhabitants of hell are given the opportunity to make a trip to heaven. One of them is a liberal Anglican theologian who, during his life on earth had made it to becoming a bishop. Caricaturing the bishop as being overweight, Lewis calls this inhabitant of hell the 'fat ghost' (Lewis 1946:33). On his arrival in heaven, this bishop meets one of the priests of his former diocese whom he reproaches: 'You became rather narrow-minded towards the end of your life. ... You were coming to believe in a literal Heaven and Hell!' Although this bishop had already spent some time in hell at the time and was now on a visit to heaven, he still lacks the discriminatory power to discover the nature of his own surroundings. He believes in the existence of neither heaven nor hell and on being told that he has been in both, he first thinks that hell is heaven (Lewis 1946:34-35). In short, the man is in total confusion.

Because of his apostasy, the bishop was sent to hell. However, he himself considers this impossible; even once hell has become his home base, he continues to insist that God cannot punish people for 'their honest opinions' (Lewis 1946:36). By the words of the priest, who had been a kindred spirit of the bishop in his early years, Lewis (1946) questions this honesty:

2.I do not know of any previous publications on this specific subject.
Our opinions were not honestly come by. We simply found ourselves in contact with a certain current of ideas and plunged into it because it seemed modern and successful. At College, you know, we just started automatically writing the kind of essays that got good marks and saying the kind of things that won applause. When, in our whole lives, did we honestly face ... the one question on which all turned: whether after all the Supernatural might not in fact occur? When did we put up one moment's real resistance to the loss of our faith? ... Having allowed oneself to drift, unresisting, unpraying, accepting every half-conscious solicitation from our desires, we reached a point where we no longer believed the Faith. Just in the same way ... a drunkard reaches a point at which (for the moment) he actually believes that another glass will do him no harm. (pp. 36-38)

On Lewis's account, this liberal theologian is not only wrong, but also insincere. And the freedom of inquiry to which the bishop attaches so much value does not deserve that name. After all, 'Thirst was made for water, inquiry for truth'. Inquiry that pays equal respect to all outcomes, including untrue ones, has as little to do with the ends of intelligence as masturbation with the ends of marriage. ${ }^{3}$

Even though Lewis suggests in The Great Divorce that his account of the apostasy of the 'fat ghost' can be seen as 'a sketch of the genesis of liberal theology in general', one might suppose that Lewis would never go so far as to project the account of the stupid, insincere and dishonest career theologian he presented in The Great Divorce on real theologians. Eighteen years later, however, Lewis reacted in similar terms to the then sensational bestseller Honest to God by Bishop John A.T. Robinson. Influenced by Bonhoeffer, Bultmann and Tillich, Robinson rejects the existence of a God above or outside us. Asked about his opinion about Honest to God, Lewis said, 'I prefer being honest to being "honest to God"', thus again suggesting that liberal theology is dishonest. And here also, Lewis took recourse to a less subtle sexual comparison:

Wirt: What is your opinion of the kind of writing being done within the Christian church today?

Lewis: A great deal of what is being published by writers in the religious tradition is a scandal and is actually turning people away from the church. The liberal writers who are continually accommodating and whittling down the truth of the Gospel are responsible. I cannot understand how a man can appear in print claiming to disbelieve everything that he presupposes when he puts on the surplice. I feel it is a form of prostitution.

Wirt: What do you think of the controversial new book, Honest to God, by John Robinson, the bishop of Woolwich?

Lewis: I prefer being honest to being "honest to God" ${ }^{4}$

What exactly does Lewis mean here when he accuses Robinson of 'a form of prostitution'? The preceding sentence runs: 'I cannot understand how a man can appear in print claiming to disbelieve everything that he presupposes when he puts on 3.The comparison is Lewis's (1946:41)

4.Sherwood Eliot Wirt posed the questions in this final interview with C.S. Lewis. See Wirt (1963.260). Lewis declined most invitations to react to Robinson's book because, as he explained in a letter to Edward Dell of The Episcopalian in New York he wanted to keep 'out of all dog-fights between professional schools of "Christian" thought' (Hooper 1996:116). Note the quotation marks around the term 'Christian', suggesting that there is not much of Christianity left in Robinson. 
the surplice'. I suspect Lewis means that Robinson and prostitutes have in common that they perform actions without accepting the presuppositions of those actions. The prostitute performs sexual acts without accepting the presupposition of those acts (namely mutual love). Similarly, Bishop Robinson performs liturgical acts of which he does not endorse the presuppositions. Both do so with a view to rewards not intrinsically connected to their acts: in the case of the prostitute, money, and in the case of the clergyman, an ecclesiastical career and respect. If we interpret Lewis's comparison in this way, we may think it unfair and disagree with it, but it is crystal clear. However, if this interpretation is correct, it would be the bishop's liturgical agency that would be compared to prostitution, not his theologising. And then Lewis should have concluded that Robinson should have withdrawn from his ministry, not from doing liberal theology. It is the kind of writing being done within the Christian church today'; however, that is the object of Lewis's critique. To return to prostitution, it is as if Lewis rebukes prostitutes for not sufficiently loving their clients.

Would Lewis be so carried away by his dislike for liberal theologians that the clarity of expression he is known for leaves him in this part of the interview? In any case, it is striking that Lewis employs similar blunt sexual analogies both for the fictitious bishop and for the real one. This is more remarkable because Lewis certainly was not in the habit of embellishing his prose and strengthening his argument with sexual invectives.

That Lewis was inclined to accuse John A.T. Robinson of the wrong motives seems to be confirmed by the following quote from the former vicar of Holy Trinity Church Headington, where Lewis attended while living at the Kilns. Roger Head comments on a conversation he had with Lewis on Bishop Robinson:

The professor [C.S. Lewis - MS] was what one would call properly and strictly orthodox. ... His writings, like his conversation, were designed to support the faith and to fortify the faithful, a thing not notable in twentieth-century theology: too frequently it tends to do the opposite and is designed for that purpose. (Head 2015:184; [authors' own italics])

Even though Head does not explicitly claim that Lewis accused modern theologians of having evil intentions, it is remarkable that this pops up in a recollection of a conversation with Lewis. In light of the above, it seems likely that the quotation reflects the views of Lewis.

\section{Bulverism}

In the two texts just discussed, Lewis did not play the ball but the man. This is all the more striking because Lewis is guilty here of what he himself denounces elsewhere as Bulverism: one assumes that someone else is wrong and consequently rebuts that person by explaining how he came to his misguided ideas (Lewis 1941):

Some day I am going to write the biography of its imaginary inventor, Ezekiel Bulver, whose destiny was determined at the age of five when he heard his mother say to his father - who had been maintaining that two sides of a triangle were together greater than the third - 'Oh, you say that because you are a man!' 'At that moment', E. Bulver assures us, 'there flashed across my opening mind the great truth that refutation is no necessary part of argument. Assume that your opponent is wrong, and then explain his error, and the world will be at your feet'. (p. 20)

This is exactly what Lewis himself does here: discrediting the views of liberal theologians not by showing these to be wrong, but by insinuating that these theologians profit from their beliefs. The 'fat ghost' is accused of seeking to ingratiate himself with his teachers and church superiors, the bishop of Woolwich of pursuing personal gain. Admittedly, these two texts are not altogether characteristic for Lewis. Lewis tried to avoid the temptation to enter into debates about the theological questions that divided Christianity, and preferred 'to explain and defend the belief that has been common to nearly all Christians at all times' (Lewis 1952:6). ${ }^{5}$ Moreover, elsewhere Lewis (1964) explicitly states as his conviction about liberal theologians that:

it would be unpardonable if we allowed ourselves any resentment against them. ... The liberals are honest men and preach their version of Christianity, as we preach ours, because they believe it to be true. (p. 22)

That he does not stick to his own principles in these two instances, then, seems to suggest that he must have been terribly annoyed by something. Otherwise he would not have gone against his own standards.

\section{What was it that bothered Lewis so much about theology?}

Elsewhere Lewis makes clear what it was that bothered him. In his 'Answers to Questions on Christianity', Lewis answers the question of whether theological differences of opinion should continue to be church-separating. His answer is telling. He says that division is a sin and must be made undone as soon as possible, and tells from his own experience that as long as you stand up for orthodox dogmatic positions, you get support from every conceivable church denomination. The division is not so great at all, unless you also look at the liberals:

The world of dogmatic Christianity is a place in which thousands of people of quite different types keep on saying the same thing, and the world of 'broad-mindedness' and watered-down 'religion' is a world where a small group of people (all of the same type) say totally different things and change their minds every few minutes. We shall never get reunion from them. (Lewis 1944a:60)

The picture Lewis sketches here is that of a large core of orthodox Christians in various churches who are very much in agreement with each other on almost everything, and around it a shell of liberals who do not agree on anything. Lewis suggests that these liberals have left the Christian house in anything but name. This is also the suggestion 5.See also note 4 above. 
behind the invective 'prostitution', which he uses for Bishop Robinson's behaviour: The man should no longer perform his priestly functions because he no longer shares the Christian beliefs that are presupposed in the liturgy. In his Letters to Malcolm, Lewis says that liberals have 'some vestigial religion which they (not we) can describe as "Christianity"' (Lewis 1964:22). Here, Lewis seems to imply that his criticism of liberals like Robinson is no longer a critique of a fellow Christian theologian, but a critique of someone who left Christianity behind.

Why does Lewis judge that liberal theology comes close to apostasy? Liberal theologians remove the supernatural, transcendent and miraculous from Christianity. According to them, in our time we can no longer believe what has not been confirmed by empirical science (Lewis 1945:77, 1959:198). In their demythologisation of Christianity - the term 'demythologisation' makes clear that Lewis, who was writing at the zenith of Rudolf Bultmann's reputation, has Bultmannstyle liberals in mind - they seek to rid the Christian faith of an ancient worldview in which they see an obstacle to its acceptance. For them, this ancient worldview and all that goes with it does not belong to the essence of Christianity, and Christianity is 'adjustable to contemporary thought' (Lewis 1964:19).

Lewis could not disagree more. He is convinced that 'Christianity essentially involves the supernatural' (Lewis 1964:22) and that 'Christianity is precisely the one religion from which the miraculous cannot be separated' (Lewis 1945:76). For him, it is therefore certain that, in such reinterpretations, something essential disappears from Christianity, so that what remains is no longer worthy of the name (Lewis 1944a:60, 1945:76). It is not that Lewis is opposed to each and every new attempt at articulating the Christian faith. For him, however, the limits of such new articulations are given in the 'objective reality' of God: we have an 'Other to reckon with' (Lewis 1964:19).

This analysis is confirmed by Lewis's only published article against liberalism, Fern-Seed and Elephants. When visiting Kenneth Carey, the later bishop of Edinburgh, Lewis explained to him that he thinks it extremely unlikely that liberal theologian Alec Vidler is right that the miracles in the Bible should actually be understood as parables. Would the church really discover the true meaning of miracles only after 2000 years? In reaction, Carey, at the time principal of Westcott House, Cambridge, invited Lewis to come and speak on this to his theology students. This invitation resulted in the lecture 'Fern-Seed and Elephants' (Lewis 1959) in which Lewis focuses on historical criticism and especially on Rudolf Bultmann. He has the following objections. Firstly, Bultmann and related New Testament scholars read the Gospels and Acts not as history, but as legends, myths, romances and poetry. In Lewis's eyes, they lack the most elementary competence to make that kind of judgement.
'They seem to me to lack literary judgment, to be imperceptive about the very quality of the texts they are reading'. And he continues by explaining:

It sounds a strange charge to bring against men who have been steeped in those books all their lives. But that might be just the trouble. A man who has spent his youth and manhood in the minute study of New Testament texts and of other people's studies of them, whose literary experiences of those texts 'lacks' any standard of comparison such as can only grow from a wide and deep and genial experience of literature in general, is, I should think, very likely to miss the obvious things about them. If he tells me that something in a Gospel is legend or romance, I want to know how many legends and romances he has read, how well his palate is trained in detecting them by the flavour; not how many years he has spent on that Gospel. (Lewis 1959:193)

Consequently, Lewis (1959), himself an astute literary scholar, shows by means of some examples the elementary mistakes the New Testament scholars make in their discussions of the literary characteristics of the New Testament texts. His devastating conclusion is:

These men ask me to believe they can read between the lines of the old texts; the evidence is their obvious inability to read (in any sense worth discussing) the lines themselves. They claim to see fern-seed and can't see an elephant ten yards away in broad daylight. (p. 197)

His second criticism of contemporary New Testament scholarship concerns their contention that Christians for 2000 years have failed to understand what the New Testament really meant, only to discover it in the 20th century. After having discussed parallel claims on the interpretation of Plato and Shakespeare, Lewis concludes: The idea that the New Testament (Lewis 1959):

[S]hould be opaque to those who lived in the same culture, spoke the same language, shared the same habitual imagery and unconscious assumptions, and yet be transparent to those who have none of these advantages, is in my opinion preposterous. (p. 198)

Lewis's third objection is that the New Testament scholars concerned assume a priori that miracles and correct predictions of the future are impossible. In doing so, they smuggle into their exegesis an assumption that is foreign to the texts of the New Testament. This assumption, moreover, is philosophical rather than scientific; scholars bring this assumption to the texts rather than learning it from the texts (Lewis 1959:198).

Lewis's final objection is based on his experiences with reviews of his own work. Critics were almost always wrong when they speculated about the influences Lewis had undergone, the intentions he had with his text, and the passages in which he was more and less involved. Why should the informed speculations of historical critics of the New Testament - who come from a completely different culture than the New Testament itself - be more reliable (Lewis 1959:198-202)? 
Lewis was well versed in the New Testament science and had a keen eye for it. In a recent evaluation, the New Testament scholar Richard Bauckham admits that Lewis was largely right, although he also had his blind spots (Bauckham 2013; cf. Vanhoozer 2010). A blind spot that falls outside the scope of Bauckham's evaluation is that Lewis's criticism of liberal theology focuses on only one theological discipline: the New Testament exegesis. As a literary scholar, Lewis felt best at home in this field, but still, theology is more than New Testament exegesis.

\section{The theological creativity of Lewis and other theologians}

It may be Lewis's overconcentration on New Testament scholarship that prevented him from noticing that he himself deviated in part from 'the belief that has been common to nearly all Christians at all times' (Lewis 1952:6). One obvious example is his understanding of life after death. Both in The Great Divorce and in The Problem of Pain Lewis defends the existence of heaven and hell. However, the view of heaven and hell that Lewis presents differs from traditional Christian faith on at least four points.

First of all, for Lewis hell is not a place (Lewis 1940:113). In this way, Lewis reinterprets Christian faith in light of the developments in cosmology since Copernicus, which left no room for heaven and hell. Since then, they have often been characterised as states rather than places (Laufer 2013:75, 86, 98, 102-103). That Lewis indeed intends to reinterpret dogma in the light of new scientific insights is confirmed by his essay Dogma and the Universe. Here Lewis discusses the possibility that, under the influence of new scientific insights, beliefs will have to be reformulated. As an example, he explicitly mentions the development from a spatial to a nonspatial view of heaven. Such doctrinal developments can only take place, Lewis claims, when the change 'touches ... what does not matter' (Lewis 1943a:46). I assume that by this Lewis means that the change must be religiously irrelevant. This, however, does not apply to the following three changes in the conception of hell that are also introduced in The Great Divorce.

The second revision Lewis defends both in The Great Divorce and elsewhere is that he leaves room for post mortem conversions. Conversion is possible even for those in hell; he famously claimed that 'the doors of hell are locked on the inside' (Lewis 1940:115; cf. 111). Thus, he reinterprets traditional doctrine in light of developments in our views on the functions of punishment. While in the past punishment functioned as retribution, as a deterrent and as a protection of the population, today reform and rehabilitation have taken the place of retribution. Lewis calls this new view on punishment 'the humanitarian theory of punishment'. If one accepts this theory and sees rehabilitation as the primary function of punishment, an eternal hell would be dysfunctional punishment and should therefore be rejected, and this is what many contemporary theologians do. Hell then becomes a place of purification rather than of retribution (Laufer 2013:104-106).
In his essay on the humanitarian theory of punishment, Lewis tries to show that it is not humanitarian at all.

The deterrent function of punishment will sometimes be served by punishments that are too severe (and therefore unjust) and even by punishing the innocent, as long as the public does not know that the innocent is innocent. Also, the protection of society may lead to punishments that are too severe. Rehabilitation, finally, is beset with problems, one of them being that a prisoner who does not reform may face a life of imprisonment. For Lewis, punishment is just only if it is deserved; therefore, retribution should be the basis of punishment (Lewis 1949). Nevertheless, in his view on hell, Lewis comes close to the purification view.

In The Great Divorce, a number of inhabitants of hell are given the opportunity to make a trip to heaven, and those who adapt to life in heaven - which means a radical reorientation of their lives - are allowed to remain there. This does not mean that Lewis opts for universalism; we have free will, and we may abuse this free will by saying no to God.

I believe that if a million chances were likely to do good, they would be given. But a master often knows, when boys and parents do not, that it is really useless to send a boy in for a certain examination again. Finality must come some time, and it does not require a very robust faith to believe that omniscience knows when. (Lewis 1940:112)

There are only two kinds of people in the end: those who say to God, 'Thy will be done', and those to whom God says, in the end, 'Thy will be done'. All that are in Hell, choose it. Without that self-choice there could be no Hell. No soul that seriously and constantly desires joy will ever miss it. Those who seek find. To those who knock it is opened. (Lewis 1946:75)

As to the third modification of the traditional doctrine of the afterlife that Lewis admits, he seems to be influenced by the modern difficulty with eternal punishment for temporary crimes. Are they not unjust? ${ }^{6}$ Lewis recoils from the eternity of hell; he says we cannot know if hell will last forever, and he characterises hell as 'the outer rim where being fades away into nonentity' (Lewis 1940:115). Because we are dependent on our Creator for our existence, whoever turns against the Creator definitively loses his existence. But everything that has existed leaves traces behind. When a block of wood is burnt, gases, heat and ashes remain. Does something similar not apply to souls too? 'If soul can be destroyed, must there not be a state of having been a human soul?' And might this not be what is traditionally characterised by the terms of 'being in hell' (Lewis 1940:113; cf. Lewis 1943b:302-303)? In other words, people in heaven and people in hell do not exist in the same way. 'Hell is in no sense parallel to heaven: it is the "darkness outside"' (Lewis 1940:115). In heaven you can be, but in hell one exists precisely by no longer being. Whoever refuses to be dependent on God, whoever wants to be autonomous and to exist on his own, egocentric, is lost (Lewis 1940:63-64).

6.See Laufer (2013:102-108). Here, there may be a parallel to Lewis's objections to life imprisonment as possibly unjust. See Lewis (1949). 
Fourthly, Lewis no longer believes that the torment of the unfortunate in hell will serve the elect in heaven as entertainment (cf. Laufer 2013:106). Conversely, he does not accept either that the elect in heaven cannot be happy as long as there is someone left in hell. This is closely connected to the previous point: for Lewis, 'in hell' is no parallel of 'in heaven'; people are in heaven, but not in hell. In other words, being in hell is not a form of existence, nor is it a form of nonexistence. It is existence moving towards non-existence without having attained that condition. Pain and torture play no role in Lewis's conception of hell. Thus, it makes no sense to worry about those in hell.

Given the importance that heaven and hell have had - and often still have - in the Christian theological and dogmatic tradition, these are certainly no marginal changes. For many Christians over the centuries, fear of hell has been an important motivating force. Major Christian churches still hold on to the doctrine of hell today. Lewis's views on heaven and hell are, in important respects, further developments of the traditional views that the church had held during the first 15 centuries of its existence. He gives a creative, in some respects even original, reinterpretation. For me, this speaks in favour of Lewis. Theologians cannot be satisfied with repeating what has been said before; they should articulate doctrine in a way that is both accessible to and plausible for their contemporaries. Sometimes this requires a mere change of words, but in other cases more is needed. The traditional depiction of hell in terms of unspeakably horrible torture fails to do justice to God as we get to know him in scripture. At the same time, Jesus is very clear: Our actions here and now do have consequences in the hereafter. That we reject the imaginative depiction of hell in terms of torture cannot mean that we reject the idea of hell altogether. ${ }^{7}$

Although I agree with Lewis that the traditional doctrine of hell as a place of unspeakably horrible torture is in need of revision, this does take away that Lewis takes a liberty here that he does not grant to the theologians whom he criticises. One might argue, of course, that their revisions go way beyond Lewis's. But is it true that faith in miracles is more central to the Christian faith than the conviction that this life is decisive and that after death we receive no second, third and fourth chances? Once more, one can object that the liberal revision of the Christian faith goes further than rejecting the miraculous. Liberal theologians undermine more fundamental truths, like the belief that God exists. In The Great Divorce, Lewis (1946) records the following dialogue between the priest and the bishop:

Priest: Do you not even believe that He exists?

Bishop: Exists? What does Existence mean? You will keep on implying some sort of static, ready-made reality which is, so to speak, 'there', and to which our minds have simply to conform. These great mysteries cannot be approached in that way. If there were such a thing ... quite frankly, I should not be interested in it. It would be of no religious significance. God, for me, is something purely spiritual. (p. 42)

7.In the most authoritative Dutch Bible translation, the Nieuwe Bijbelvertaling (2004) the term 'hell' (in Dutch: 'hel') does not appear at all.
Here, Lewis lets his personage of the 'fat ghost' express a view adopted by many liberal theologians: believing in God is something other than believing that God exists. 'Existence' is the term we use for empirically observable objects. When we apply this term to God, we speak disparagingly of God, we make Him an additional object in this world, we deny His otherness, His transcendence, His spirituality. If these are the objections to the application of the term existence to God, the refusal to use this term for God means quite something different from believing that God does not exist. It is the denial that the term existence is applicable to God: To say that God exists is to commit a category mistake. What we experience as ... more shocking is that the... denial or the affirmation of the existence of God depends on the theoretical framework within which we theologise (Sarot 2013).

Both the idea that hell is a physical space where sinners are punished eternally and without the possibility of repentance, and the application of the modern concept of existence to God, are forms of thought that are alien to the Bible. They entered the Christian faith only later on. When one rejects the one (which relates to our representation of hell) and accepts the other (which relates to the 'existence' of God), one needs criteria on the basis of which to make this assessment. In the only essay he has written on this subject, Dogma and the Universe, Lewis seems to allow only religiously irrelevant developments, while we have seen that in practice he also allows religiously relevant developments. The criterion he explicitly develops does not match the criterion he implicitly applies, then. My suggestion would be that implicitly, Lewis's most important criterion was the lex orandi: the practice of Christian faith. Lewis accepted theological views that were compatible with the practice of Christian faith or supported it, and rejected views that undermined it. For him, refusing to say that God exists falls in the last category (it undermines faith), while refusing to accept that hell is a torture chamber falls in the first category (it makes faith more plausible).

\section{Conclusion}

In summary, I would like to state that the tense relationship between Lewis and the theologians of his time was not only because of these theologians but also because of ... Lewis himself. Although he intended not to become a party in theological controversies, he sometimes felt compelled to take sides. He expressed himself in extremely negative terms about the liberal movement which, in his experience, dominated the theology of his time. At these moments he sometimes engaged in what he himself chastised as 'Bulverism', assuming that the theologians in question were wrong, and showing how they had arrived at their errors. He did not avoid the use of pejorative, sexually tinged metaphors. At these moments Lewis was uncompromising, but not gentle. ${ }^{8}$ Only on one occasion did Lewis provide arguments for his rejection of liberal theology, and on that 8.According to the blurb text of the edition of Christian Reflections that I use here, Lewis was 'unyielding though infinitely gentle'. 
occasion he limited himself to the New Testament exegesis. On another occasion Lewis states that he allows only marginal, religiously irrelevant revisions of Christian doctrine. Ironically, his own revisions sometimes - for example, in the case of the traditional doctrine of hell - went beyond this. Implicitly, so I have suggested, for Lewis the practice of faith is the ultimate criterion.

\section{Acknowledgements}

The author thanks Aart Nederveen, Arend Smilde, Bart-Jan Spruyt and this journal's reviewers for their comments on earlier drafts of this article. A shortened and popularised version has been published in Dutch in Wapenveld 68/1 (February 2018), 27-33.

\section{Competing interests}

The author declares that no competing interest exists.

\section{Authors' contribution}

M.S. is the sole author of this article.

\section{Ethical consideration}

The research for this article was limited to the analysis of literature that is publicly available as a result of having been published, and that was interpreted with due caution in accordance with the standards that are considered appropriate with the philosophy of religion.

\section{Funding Information}

This research received no specific grant from any funding agency in the public, commercial or not-for-profit sectors.

\section{Data availability statement}

Data sharing is not applicable to this article as no new data were created or analysed in this study.

\section{Disclaimer}

The views and opinions expressed in this article are those of the authors and do not necessarily reflect the official policy or position of any affiliated agency of the authors.

\section{References}

Bauckham, R., 2013, 'Are we still missing the elephant? C.S. Lewis's "Fernseed and Elephants" half a century on', Theology 116(6), 427-434. https://doi.org/ 10.1177/0040571X13500457

Dorsett, L.W. \& Hanson, J., 2007, 'C.S. Lewis and Joy Davidman: Severe Mercies, late romance', in B.L. Edwards (ed.), C.S. Lewis: Life, works, and legacy, vol. 1, pp. 275-293, Praeger, Westport, CT.

Gilley, G., 2006, 'C.S. Lewis', Tottministries 12(8), September, viewed 30 April 2019, from https://tottministries.org/cs-lewis/.

Head, R., 2015, 'C.S. Lewis as a parishioner', in R. White, J. Wolfe \& B.N. Wolfe (eds.), C.S. Lewis and his circle: Essays and memoirs from the Oxford C.S. Lewis Society, pp. 179-186, OUP, Oxford.

Hooper, W., 1996, C.S. Lewis: A companion \& guide, Harper Collins, London.

Laufer, C.E., 2013, Hell's destruction: An exploration of Christ's descent to the dead, Ashgate, Farnham.

Lewis, C.S., 1940, The problem of pain, Geoffrey Bles, London, ${ }^{17} 1946$.

Lewis, C.S., 1941, 'Bulverism', in C.S. Lewis (ed.), Compelling reason, pp. 18-22, Harper Collins, London.

Lewis, C.S., 1943a, 'Dogma and the universe', in C.S. Lewis (ed.), God in the dock: Essays on theology and ethics, pp. 38-47, Eerdmans, Grand Rapids, MI.

Lewis, C.S., 1943b, Perelandra. Out of the silent planet/Perelandra, pp.169-400, Harper Collins, London, 2001.

Lewis, C.S., 1944a, 'Answers to questions on Christianity', in C.S. Lewis (ed.), God in the dock: Essays on theology and ethics, pp. 48-62, Eerdmans, Grand Rapids, MI.

Lewis, C.S., 1944b, 'Rejoinder to Dr Pittenger', in C.S. Lewis (ed.), God in the dock: Essays on theology and ethics, pp. 177-183, Eerdmans, Grand Rapids, MI.

Lewis, C.S., 1945, 'Christian apologetics', in C.S. Lewis (ed.), Compelling reason, pp. 64-80, Fount Paperbacks, London, rpt. 1996.

Lewis, C.S., 1946, The great divorce, Signature Classics Edition published by HarperCollins, London, 2002.

Lewis, C.S., 1949, 'The humanitarian theory of punishment' (1949), in C.S. Lewis (ed.), Compelling reason, pp. 127-142, Fount Paperbacks, London, rpt. 1996.

Lewis, C.S., 1952, Mere Christianity, Fontana, London, 1955.

Lewis, C.S., 1959, 'Fern-seed and Elephants' in C.S. Lewis (ed.), Christian reflections, pp. 191-208, Fount Paperbacks, London, ${ }^{4} 1988$.

Lewis, C.S., 1963, 'To Jocelyn Gibb', in P.F. Ford (ed.), Yours, Jack; Spiritual direction from C.S. Lewis, pp. 370-371, Harper Collins, New York.

Lewis, C.S., 1964, Letters to Malcolm: Chiefly on prayer, Geoffrey Bless, London [on Internet: Project Gutenberg; quoted by letter number].

MacSwain, R., 2010, 'Introduction', in R. MacSwain \& M. Ward (eds.), The Cambridge companion to C.S. Lewis, pp. 1-12, CUP, Cambridge.

Nieuwe Bijbelvertaling, 2004, Bijbel: Nieuwe Bijbelvertaling uitgegeven door het Nederlands Bijbelgenootschap in samenwerking met de Katholieke Bijbelstichting, Boekencentrum, Zoetermeer.

Pittenger, N., 1950, 'A critique of C.S. Lewis', The Christian Century 75(October 1), 1104-1107.

Sarot, M., 2013, 'Niet echt gebeurd maar wel waar? Een analyse van de verschillen tussen propositionele en non-propositionele benaderingen van de theologie', Kerk en theologie 64, 205-218.

Travers, M., 2007, 'The letters of C.S. Lewis: C.S. Lewis as correspondent', in B.L. Edwards (ed.), C.S. Lewis: Life, works, and legacy, vol. 4, pp. 19-47, Praeger, Westport, CT.

Vanhoozer, K.J., 2010, 'On scripture', in R. MacSwain \& M. Ward (eds.), The Cambridge companion to C.S. Lewis, pp. 75-88, CUP, Cambridge.

Vaus, W., 2007, 'Lewis in Cambridge: The professorial years (1954-1963)', in B.L. Edwards (ed.), C.S. Lewis: Life, works, and legacy, vol. 1, pp. 197-218, Praeger, Westport, CT.

Wirt, S. E., 1963, 'Cross-examination', in C.S. Lewis (ed.), God in the dock: Essays on theology and ethics, pp. 258-267, Eerdmans, Grand Rapids, MI.

Wright, N. T., 2007, 'Simply Lewis', Touchstone: A Journal of Mere Christianity, March, viewed 13 April 2019, from http://www.touchstonemag.com/archives/article. php?id=20-02-028-f. 